\title{
Spinal ankylosing spondylitis: a variant form of ankylosing spondylitis or a distinct disease entity?
}

\author{
J T GRAN, ${ }^{1}$ G HUSBY, ${ }^{1}$ AND M HORDVIK
}

From the ${ }^{1}$ Department of Rheumatology and ${ }^{2}$ Department of Radiology, Institute of Clinical Medicine, University of Troms $\emptyset$, Troms $\emptyset$, Norway

SUMMARY In a population survey of ankylosing spondylitis (AS) seven subjects, six males and

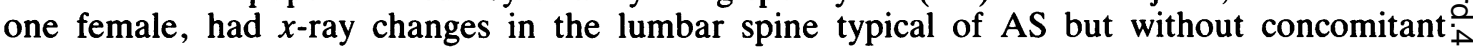
roentgenological sacroiliitis. The overall prevalence of such cases in the population studied was $0 \cdot 37 \%$. Four out of these seven subjects carried the tissue antigen HLA-B27 (57\%). The clinical $\dot{\omega}$ and roentgenological features of these subjects are described and it is suggested that the $x$-ray $\infty$ findings represent a mild and variant form of primary or definite AS.

Key words: population survey, HLA-B27, ankylosing spondylitis sine sacroiliitis.

The radiological appearance of arthritic changes in the sacroiliac joints (SIJ) has been regarded traditionally as the hallmark of ankylosing spondylitis (AS) ${ }^{1}$ Consequently the definition of AS according to established criteria ${ }^{2}$ rests firmly on the demonstration of such roentgenological features. In addition to sacroiliitis, however, arthritic changes in the spine visualised by $x$-ray develop in some $57-88 \%$ of the patients. ${ }^{34}$ These spinal $x$-ray changes develop later in the course of AS and usually after radiological sacroiliitis is evident. ${ }^{5}$ Spinal $x$-ray changes typical of AS may, however, occasionally be the first demonstrable sign of the disease ${ }^{6}$ and are initially most frequently located in the dorsolumbar junction. ${ }^{7}$ There are, however, conflicting opinions as to whether or not spinal $x$-ray changes characteristic of AS can develop as the only sign of this rheumatic disorder. ${ }^{89}$

We have recently performed an epidemiological survey of $\mathrm{AS},{ }^{10}$ which gave us the opportunity to study some aspects of the spinal $x$-ray changes typical of AS. The purpose of the present study was to focus on some clinical and laboratory features in patients with spinal $x$-ray changes, who were lacking concomitant radiological sacroiliitis (spinal AS).

\section{Materials and methods}

EPIDEMIOLOGICAL SURVEY

An epidemiological survey (The Troms $\emptyset$ Heart

Accepted for publication 10 January 1985 .

Correspondence to Dr J T Gran, Lillehammer Sanitetsforenings

Revmatismesykehus, 2600 Lillehammer, Norway.

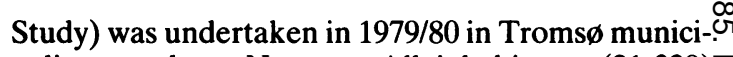
pality, northern Norway. All inhabitants (21 329)ס aged 20-49 years (females) and 20-54 years (males) were invited to participate; of these, 16621 persons attended the screening. The 14539 participants who returned a questionnaire consisting of three ques- $\bar{\Phi}$ tions about back pain were the subjects of the $\overrightarrow{\vec{F}}$ present analysis. Table 1 shows that 2907 subjects of the 14539 responders complained of pain or stiff-? ness of the back, or both. Of these 2907 positive responders a random sample of 806 subjects $(28 \%)$ was drawn by offering those who were born on 120 randomly selected days in a month clinical examina-음 tion. Of the 806 invited subjects, $449(56 \%)$ volun teered for clinical examination.

DIAGNOSTIC CRITERIA

The New York criteria ${ }^{2}$ for definite AS were applied and only patients with definite $x$-ray changes in the sacroiliac joints (SIJ) were accepted as definite AS. Patients with accompanying psoriasis, Reiter's disease, inflammatory bowel disease, or juvenile onset 0 AS (age 15 years or younger) were excluded. $\omega$ Accordingly one person with juvenile onset AS was excluded.

ROENTGENOLOGICAL GRADING SYSTEM The grading system of Dale ${ }^{11}$ for arthritic changes in the SIJ was used, in which grades II-IV represent $\frac{0}{\mathbb{1}}$ definite arthritic changes, and consequently correspond to the New York criteria ${ }^{2}$ grades III-IV. The@ morphological changes used to assess spinal $x$-ray involvement were: syndesmophytes, 'shining cor- $\Omega$ 
ners', 'squaring', arthritis of the apophyseal joints, spondylodiscitis, and 'bamboo spine'. When differentiation between osteophytes and syndesmophytes was difficult the morphological changes were termed mixtaosteophytes and were not counted as a radiological feature typical of AS.

\section{ROENTGENOLOGICAL EXAMINATION}

Standard $x$-rays of the SIJ (anterior-posterior and posterior-anterior views) and the dorsolumbar junction (anterior-posterior and lateral views) were obtained. All persons who underwent clinical examination were requested to attend for radiological examination, except those for whom appropriate films taken not more than two years before examination ( 25 subjects) were available. The $x$-ray examination followed the clinical examination, and 350 subjects volunteered for such an investigation. In this way $x$-rays of 375 of the 449 persons examined clinically $(83.5 \%)$ were obtained. These 375 films were read by a radiologist who was unaware of the clinical status of the patients. An observer variation study of the grading system has been previously performed. ${ }^{12}$ The results of this study showed that in $96.9 \%$ of the films the two observers could agree on whether definite arthritic changes were present or not. The films $(3 \cdot 1 \%)$ where agreement was not achieved were interpreted by a third radiologist whose decisions were accepted as final.

\section{TYPING FOR HLA-B 27}

The typing of HLA-B27 was performed according to standard techniques previously described. ${ }^{13}$ An attempt was made to tissue type all 449 subjects either at the clinical examination or later at the roentgenological examination. As some persons who were supposed to be tissue typed at the roentgenological examination did not attend for this investigation, tissue typing was only successfully accomplished in 380 persons $(84 \cdot 6 \%)$.

CLINICAL EXAMINATION

The clinical examination was performed without knowledge of the results of the $x$-ray examination or B27 typing. The test for lumbar mobility was performed according to the method described by Macrae and Wright. ${ }^{14}$ Total spinal mobility (except for the cervical spine) was determined with a spondylometer, ${ }^{15}$ and $40^{\circ}$ flexion and $20^{\circ}$ extension were used as lower limits of normal mobility. Measurements of chest expansion followed standard procedures. $^{16}$

\section{S T A T I S T I C S}

$\chi^{2}$ test and Student's $t$ test were used, and a $\mathrm{p}$ value of less than 0.05 was accepted as significant. The tests were done as two tailed, and the alpha levels were not adjusted for the number of hypotheses tested.

\section{Results}

PREVALENCE OF SPINAL AS

Among the 375 who underwent both clinical and radiological examination seven subjects, six males and one female, had $x$-ray changes in the lumbar spine typical of AS (Table 1) and without concomitant roentgenological sacroiliitis. The overall prevalence of such changes was estimated to be $0.37 \%$ in this young-middle aged population; it increased with age and reached its peak in the $50-54$ age group $(1 \cdot 54 \%)$. Twenty-seven cases of definite AS were found (prevalence $1 \cdot 1-1 \cdot 4 \%$ ) of whom $58.3 \%$ (14 out of 24 cases) had spinal $x$-ray changes typical of AS.

\section{ROENTGENOLOGICAL FINDINGS}

Table 2 shows the classification of the spinal $x$-ray changes found among the seven subjects. Five had syndesmophytosis only, while anterior spondylitis was encountered in two persons. By definition none had definite arthritic changes in the SIJ. Three of the subjects had, however, SIJ films showing changes classified as suspected sacroiliitis. No sign of ankylosis was seen in any of the films analysed.

CLINICAL CHARACTERISTICS

Table 2 lists some clinical features of the spinal AS

Table 1 Number of participating persons, those with back pain and prevalence of spinal AS in different age groups

\begin{tabular}{|c|c|c|c|c|c|c|}
\hline \multirow[t]{2}{*}{ Age group } & \multirow[t]{2}{*}{$\begin{array}{l}\text { Total } \\
\text { population }\end{array}$} & \multirow[t]{2}{*}{$\begin{array}{l}\text { No. of } \\
\text { participants }\end{array}$} & \multirow[t]{2}{*}{$\begin{array}{l}\text { Reporting back } \\
\text { pain or stiffness }\end{array}$} & \multirow[t]{2}{*}{$\begin{array}{l}\text { Examined clinically } \\
\text { and } x \text {-rayed }\end{array}$} & \multicolumn{2}{|c|}{$\begin{array}{l}\text { Prevalence of } \\
\text { spinal } A S\end{array}$} \\
\hline & & & & & No. & $\%$ \\
\hline $20-29$ & 8265 & 4887 & 678 & 61 & () & 0.00 \\
\hline $30-39$ & 7661 & 5543 & 1103 & 1.35 & 2 & 0.29 \\
\hline $40-49$ & 4319 & 3317 & 913 & 144 & 3 & 0.57 \\
\hline $50-54$ & 1084 & 792 & 213 & 35 & 2 & $1 \cdot 54$ \\
\hline Total & 21329 & 14539 & 2907 & 375 & 7 & 0.37 \\
\hline
\end{tabular}




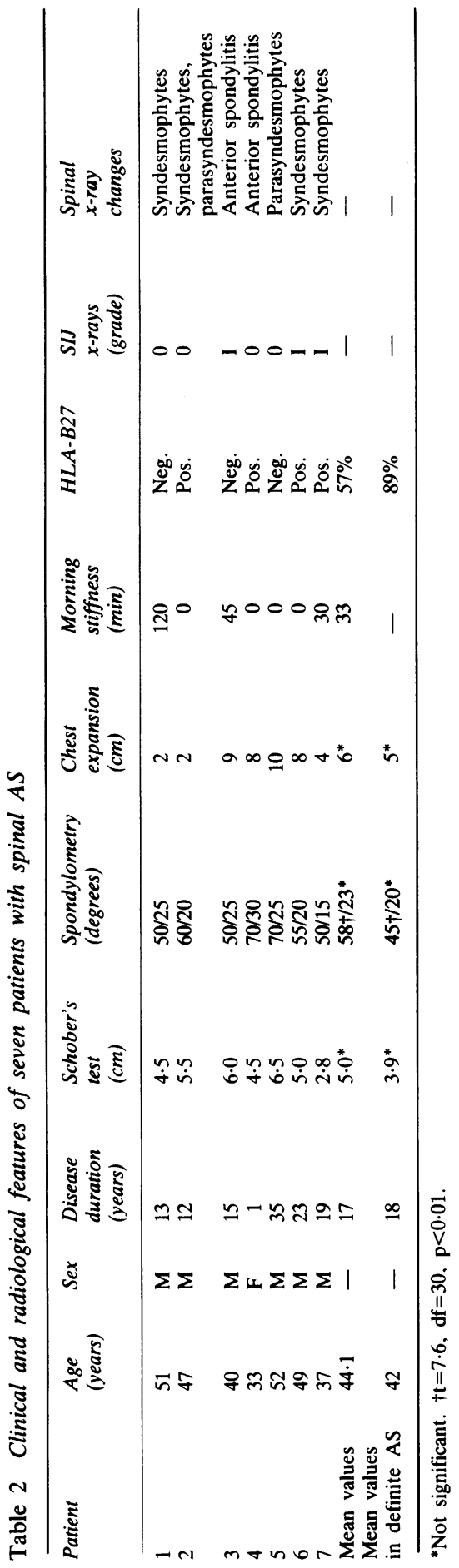

patients, and, for comparison, the findings in 27 응 patients from the same population survey suffering. from definite $\mathrm{AS}^{17}$ are also given. There were no significant differences with respect to mean age ormean disease duration between spinal AS and등 definite AS. There was a certain trend for the spinalo AS patients to have less restricted spinal mobilityळ compared with definite AS patients, but the mean lumbar flexion, the mean chest expansion, and the ${ }^{\infty}$ mean total spinal extension (spondylometry) did not $\vec{\circ}$ differ significantly between the two patient groups. $\overrightarrow{\vec{\omega}}$ Total spinal flexion, as measured by spondylometry, $\stackrel{\omega}{ }$ was, however, significantly greater in spinal AS. Unfortunately, no data concerning duration of ${ }^{\circ}$ morning stiffness for definite AS were available. $\$$

The frequency of the tissue antigen HLA-B27 was significantly higher in spinal AS $(57 \%)$ compared with the frequency among blood donor controlso $(15.9 \%)$, while it was not significantly different from ${ }^{-}$ that of definite AS (89\%).

\section{Discussion}

Most epidemiological surveys of AS have relied on the radiological appearance of sacroiliitis when estimating the prevalence of AS. Descriptions of spinal $x$-ray changes typical of AS but withouto concomitant roentgenological sacroiliitis are thus relatively uncommon. Some investigators who based $\stackrel{\varrho}{\rightarrow}$ their study on hospital patients have suggested thatô such a roentgenological constellation occurs in less than $1 \%$ of the cases with definite AS. ${ }^{18}$ Reliable comparison between the estimated prevalence of spinal AS from the present study and other calcu- $\frac{0}{2}$ lated prevalence rates is hampered by the different investigation designs. The present finding of 273 patients suffering from definite $\mathrm{AS}^{2}$ and seven patients with spinal AS in the same population 3 group may indicate that such changes are rathero frequent.

The pathogenesis and nature of the observedo spinal $x$-ray changes remain obscure; some investigators have considered them to represent a varianto of definite $\mathrm{AS},{ }^{8}$ while others ${ }^{19}$ have regarded themn as a distinct disease entity. In contrast to othern studies $^{19}$ we found the prevalence of the $A S_{\sigma}^{\omega}$ susceptibility gene HLA-B27 to be significantly increased among spinal AS patients compared with non-AS controls. This finding may be interpreted ino different ways. First, it may indicate a true association between spinal AS and definite AS, and that the spinal $x$-ray changes typical of AS represent merely early signs of definite AS. The long duration $\frac{\mathbb{}}{\mathbb{D}}$ of back pain among these subjects speaks, however, 을 against a later development of roentgenologicale 
sacroiliitis. In only one patient (No. 4) do we regard this explanation as possible. Secondly, the features may be encountered as a distinct disease entity not associated with AS but associated with HLA-B27 in common with definite AS. As long as the aetiology of definite AS is unknown this suggestion cannot be either proved or refuted. Thirdly, the spinal $x$-ray changes can be interpreted as an expression of a mild and variant form of definite AS. There was a tendency for the spinal AS patients to exhibit less restricted spinal and chest mobility compared with the patients suffering from definite AS. Due to the low number of patients with spinal AS, however, a statistically significant difference was obtained only for spondylometry flexion (Table 2). Further studies will be required to elucidate the nature of spinal AS, but it is our impression that these cases represent mild and variant expressions of AS. Prospective studies of the subjects studied should also clarify whether or not the spinal $x$-ray changes increase and eventually terminate in bony ankylosis; the long disease duration speaks against such a development.

The differentiation between spinal $x$-ray changes of AS and degenerative changes may be difficult, but classical degenerative spinal changes were lacking in our patients. Furthermore, when differentiation from degenerative changes was difficult the changes were recorded as mixtaosteophytes, and such cases were excluded from the present study.

Other disorders which sometimes lead to roentgenological abnormalities in the SIJ and that may mimic AS, e.g., tuberculosis, acromegaly, hypoparathyroidism, Paget's disease, fluorosis and metastasis of malignant diseases, were as far as possible excluded in the seven patients studied. Furthermore, the association between spinal AS and B27 cannot be related to the presence of other seronegative spondyloarthropathies, as these disorders were carefully looked for and excluded from the present patient study.

To conclude we suggest that the roentgenological findings in these patients represent a mild and variant form of primary or definite AS. A longitu- dinal study presently being conducted should eventually show if other explanations are more valid.

This work was supported by the Norwegian Research Councils for Science and Humanities, the Norwegian Women's Health Association, and the Norwegian Rheumatism Council.

\section{References}

1 West H F. The aetiology of ankylosing spondylitis. Ann Rheum Dis 1949; 8: 143-8.

2 Bennet P H, Wood P H N eds. Population studies of the rheumatic diseases. Proceedings third international symposium 1966. New York. Amsterdam: Excerpta Medica, 1968: 456-7.

3 Carette S, Graham D, Little H, Rubenstein J, Rosen P. The natural disease course of ankylosing spondylitis. Arthritis Rheum 1983; 26: 186-90.

4 Prasad P, Singh R P. Ankylosing spondylitis in Tribalt belt of Chhotanagpur region. J Indian Med Assoc 1982; 78: 108-12.

5 Moll J M H. Ankylosing spondylitis. In: Scott J T, ed. Copeman's textbook of the rheumatic diseases. 5th ed. Edinburgh: Churchill Livingstone, 1978; 511-36.

6 Jajic I, Furst Z, Vuksic B. Spondylitis erosiva: report on 9 patients. Ann Rheum Dis 1982; 41: 237-41.

7 Wilkinson M, Bywaters E G L. Clinical features and course of ankylosing spondylitis. As seen in a follow-up of 222 hospital referred cases. Ann Rheum Dis 1958; 17: 209-28.

8 Calin A. Ankylosing spondylitis sine sacroiliitis. Arthritis Rheum 1979; 22: 303-4.

9 Kåss E. Diagnostic criteria in spondylarthritis ankylopoietica. Acta Rheumatol Scand 1968; 14: 197-209.

10 Gran J T, Husby G, Hordvig M. The prevalence of ankylosing spondylitis in males and females of a young middle-aged population in Tromsø, northern Norway. Ann Rheum Dis in press.

11 Dale K. Radiographic grading of sacroiliitis in Bechterew's syndrome and allied disorders. Scand J Rheumatol 1980; suppl 32: $92-7$

12 Gran J T, Husby G. Ankylosing spondylitis: a comparative study of patients found in an epidemiological survey and those admitted to a department of rheumatology. $J$ Rheumatol in press.

13 Gran J T, Mellby A S, Husby G. The prevalence of HLA B27 in northern Norway. Scand J Rheumatol 1984; 13: 173-6.

14 Macrae I F, Wright V. Measurements of back movements. Ann Rheum Dis 1969; 28: 584-91.

15 Hart F D, Strickland D, Cliffe P. Measurements of spinal mobility. Ann Rheum Dis 1974; 33: 136-9.

16 Moll J M H, Wright V. The pattern of chest and spinal mobility in ankylosing spondylitis. Rheumatol Rehabil 1973; 12: 115-34.

17 Gran J T. An epidemiological survey of the clinical signs and symptoms in ankylosing spondylitis. Clin Rheumatol in press.

18 Polley H F, Slocumb C H. Rheumatoid spondylitis: a study of 1035 cases. Ann Intern Med 1947; 26: 240-9.

19 Courtois C, Fallet G H, Vischer T L, Wettstein P. Erosive spondylopathy. Ann Rheum Dis 1980; 39: 462-8. 